\title{
WOMEN IN BLUE: STRUCTURAL AND INDIVIDUAL DETERMINANTS OF SEX SEGREGATION IN BLUE-COLLAR OCCUPATIONS
}

\author{
Margarita Torre \\ Universidad Carlos III de Madrid
}

The number of women occupying male-dominated blue-collar jobs continues to be very low. This study examines segregation in the blue-collar trades, taking into consideration both structural and individual factors. Using nationally representative data for twentyfive countries, the study shows that segregation in the blue-collar sector does not vary with the strength of vocational education and training programs (VET). At the individual level, findings reveal higher degrees of social reproduction among working class families, but parental background alone does not fully account for the gender composition of the sector in which children end up working. Overall, the findings point to the existence of a socializing mechanism that entrenches horizontal segregation in the blue-collar sector. The study indicates that to reduce segregation in the blue-collar fields, policies must address this prior mechanism, both at the structural and individual level.

Keywords: segregation blue-collar jobs, male-dominated, vocational education and training, family background, multilevel. 


\section{INTRODUCTION}

Compared to the increasing integration of women into male-dominated professional occupations, female presence in blue-collar male-dominated jobs continues to be very low (England 2010; Cotter, Hermsen and Vanneman 2004). This general pattern is seen in many affluent nations (Charles and Grusky 2004), raising the question: Why has desegregation been limited to high-level (e.g., managerial) jobs?

The "blue-collar" sector includes a variety of manual labor positions, from the relatively high-skilled and well-remunerated (craft workers, machine operators) to low-skilled (cleaners, assembly line workers). However, most of the more lucrative blue-collar positions are held by men, while women are concentrated in unskilled and low-skilled blue-collar jobs (LBS 2017). Interesting theories have been offered as to why. Specifically, England (2010) argues that, whenever possible, women avoid working in traditionally male blue-collar jobs. Women from working-class families, in particular, have tended to satisfy their aspirations for upward mobility by turning to service or clerical occupations, thus reproducing segregation in the blue-collar field. Others note that training opportunities for women in male-dominated blue-collar trades remain limited (Bergmann 2011). This lack of progress contrasts sharply with the expansion of opportunities for women in fields such as law and medicine that has occurred over the last several decades. As a result, hiring practices in male-dominated trades are often entirely at the discretion of an employer or manager rather than following merit-based rules based on objective qualifications. Such practices open the door to cognitive biases, stereotyped decisions, and other mechanisms of out-group aversion that exacerbate segregation further (Bergmann 2011; Reskin and Maroto 2011; Torre 2014; Roth 2006). 
These debates around occupational sex segregation have produced valuable insights, but they have as of yet remained largely on the theoretical level. This article seeks to redress this dearth of empirical support by examining the individual and structural constraints to integration in blue-collar occupations. Specifically, I thoroughly study how both vocational education and training (VET) and parental background contribute to the lack of integration in blue-collar occupations. Moreover, my study widens the scope of this debate, which has primarily focused on the United States, where the employment training structure differs from those of many other countries. For example, craft and guild worker arrangements play a large role in US, while an array of formal training opportunities are more widely available in other countries. As a result, the explanations for women's underrepresentation in male-dominated craft positions have been ethnocentric. The investigation of international data presented below will help to correct this limitation in the literature.

Considering sex segregation from this wider perspective, I draw on the Labor Force Survey and rounds 4 to 8 of the European Social Survey (ESS) to compile a cumulative data set containing information for twenty-five countries ${ }^{1}$ between 2008 and 2016. I use multilevel models to explore how the probability of being employed in (sex-typed) bluecollar occupations varies across countries. At the country level, I investigate whether the scope of vocational education and training (VET) explains variation in male and female representation in blue-collar occupations across countries. At the individual level, I examine the effects of parental employment status, occupation, and educational level when the respondent was 14 years old, while controlling for the respondent's individual characteristics (age, education, marital status, parental status, and immigrant status). 
This analysis makes a theoretical as well as empirical contribution to the existing literature. First, research on occupational segregation has primarily focused on women in managerial and professional occupations. By concentrating on the experiences of middleclass women, prior literature has tended to neglect the importance of the intersectionality of gender and class when studying women entering previously male-dominated occupations. In contrast, this study pays attention to women crossing gender boundaries in blue-collar fields, where, it has been found, they have more difficulty gaining a foothold than do women entering professional occupations (Bergmann 2011; O'Farrel 1999). Also, in addressing both individual and structural factors in numerous countries, this study seeks to explain the persistence of gender inequality in the most precarious occupations across different social and economic contexts. Altogether, understanding the determinants of women's relative invisibility in male blue-collar trades is crucial to designing policies that increase access for women to these occupations. Such opportunities would significantly benefit some women of working-class origin without college degrees in traditionally female, poorly paid blue-collar jobs.

The findings are not optimistic for imminent occupational desegregation. At the country level, the data reveal that segregation levels in male-dominated blue-collar occupations are not lower in countries with higher levels of vocational educational and training. Unlike academic and professional training programs, VET does not increase the presence of women in male-dominated blue-collar jobs. At the individual level, the findings reveal a high degree of intergenerational class reproduction within the blue-collar sector. Parental background, however, does not explain the gender composition of the occupation in which children end up working. Daughters of working-class families remain largely trapped in female-dominated blue-collar occupations regardless of their parents' educational and employment background. The findings are consistent with the notion that 
comparatively low levels of egalitarian attitudes in blue-collar occupations, gendered socialization into traditional roles, and stigmas associated with gender-atypical employment choices drive both men and women of working-class origins to pursue gendered pathways within VET. This study thus calls for new policies that attempt to tackle segregation at earlier stages — within family and primary educational institutionsthereby giving VET systems and formal personnel practices a better chance of reducing gender occupational segregation.

\section{THE PERSISTENCE OF SEGREGATION IN THE LABOR MARKET: LOW- STATUS VERSUS HIGH-STATUS OCCUPATIONS}

Overall, sex segregation has declined over recent decades, with more women entering previously male-dominated occupations (England 2010; Mandel 2012; Charles and Grusky 2004; Cotter, Hermsen and Vanneman 2004), but this increasing integration has been confined to high-level, more lucrative professions (England 2010; Cotter, Hermsen and Vanneman 2004). Blue-collar occupations have not witnessed this desegregation trend. Men remain reluctant to enter female-dominated blue-collar occupations because they offer lower pay and social status than do male-dominated ones (England 2010; Jacobs 1993; Levanon, England, and Allison 2009; England et al. 1994; Glass 1990). Also, men fear the social stigma of working in traditionally female trades (Lupton 2000; Williams 1992, 1995). The question of why women are not entering male-dominated blue-collar occupations is more puzzling.

The blue-collar sector is quite heterogeneous. It refers to craft workers, plant and machine operators, and other manual laborers. The term "blue-collar" has been widely used in 
opposition to "white-collar," which refers to people in managerial and professional occupations. Identifying another category, Howe (1977) coined the term "pink-collar" to denote typical female work in the service sector, such as nurses, school teachers, and secretaries.

The more skilled occupations in the blue-collar field provide good pay and benefits, with average hourly wages below those of managerial and professional jobs but above the national average (BLS 2017). According to the Occupational Information Network $\left(\mathrm{O}^{*} \mathrm{Net}\right)^{2}$, such skilled jobs offer training and autonomy but are physically demanding and can be dangerous. Semi-skilled and unskilled jobs in the blue-collar field (e.g., assembly line workers, cleaners) pay significantly less; they require physical strength, tend to be tedious and repetitive, and often entail exposure to hazardous working conditions. Women in the blue-collar field are largely concentrated in the lowest-skilled, lowest-paying occupations. ${ }^{3}$ As many of these jobs do not provide sufficient wages to keep their families above the poverty level (Shortridge 1986; Glass 1990; Bergmann 2011), integrating into nontraditionally female blue-collar occupations would bring them significant economic gains.

A major source of controversy in the literature is whether women's position in the labor market can be explained by their preference for certain kinds of work, or whether the labor market limits opportunities for women. Human capital scholars hold that occupational sex segregation reflects different levels of human capital investment (Becker 1993; Mincer and Polachek 1974; Polachek 1981; Tam 1997). To the extent that women are concerned about juggling work and family responsibilities, they voluntary choose to enter occupations where human capital does not depreciate when they move out of the labor market for periods of childrearing. Men, however, will choose jobs that reward 
experience and a steady, continuous career path. The result, so it is argued, is a segregated labor market.

Human capital researchers have used similar logic to explain the wage variation in maleand female-dominated occupations. Building on the compensating differential hypothesis - which states that more unpleasant working conditions must pay premiums in order to be attractive to laborers (Smith, 1976; Rosen 1986) - they argue that women choose to take a larger proportion of their total compensation package in non-pecuniary amenities, whereas men opt for a larger proportion of their benefits in wages (Filer 1989). Therefore, the gender gap in earnings is also the result of gender-specific job preferences, as women gravitate towards occupations that offer more flexibility but lower salaries and prestige (Filer 1985, 1989).

Socio-cultural scholars, by contrast, are primarily concerned with the non-market variables that shape employment patterns, stressing the effect of early socialization in channeling men and women into sex-typical occupations. Gender-typical expectations acquired throughout childhood and early adulthood are carried over into the labor market, pushing men and women to self-sort into sex-typical jobs (Reskin 1993; Marini and Brinton 1984; England et al. 1994). However, it has been shown that these gender-typical expectations vary according to social class. According to the literature, parents with higher socioeconomic and educational backgrounds tend to hold more progressive views on gender roles than do parents from working-class families. As these attitudes are transferred to their sons and daughters, children from families with higher socioeconomic and educational statuses will have less stereotypically gendered occupational aspirations than children from working-class families (Polavieja and Platt 2014; Davis and Greenstein 2009). 
As for sex differences in earnings, socio-cultural scholars again disagree with their human capital counterparts. In their study, Jacobs and Steinberg (1990) investigated the tasks, working conditions, and compensation packages of both male- and female-dominated jobs. The authors compiled a list of various undesirable work features (e.g., repetition, stress, cleaning up after others) many of which corresponded to female-dominated occupations. Furthermore, and undercutting the human capital theory, lower wages in typically female jobs are not compensated by greater levels of job satisfaction, more access to part-time work, flexible hours, health insurance, paid sick or vacation days, or job-protected maternity leave (Glauber 2011). Rather the opposite, flexible working hours and other benefits that facilitate childrearing are actually more common in typically maledominated or sex-neutral jobs (Glauber 2011; Glass 1990). Given these findings, sociocultural scholars claim that the lower remuneration of female-dominated jobs stems not from a compensating differential process but rather from the devaluation of female work. This devaluation theory claims that gender biases make managers underestimate the relative contribution of work undertaken in "female" jobs (England 1992; England et al. 1994; England et al. 2000; Petersen and Morgan 1995). In other words, it is not women's preferences for certain kinds of work but rather discriminatory practices and institutional inertia that allow for segregation to persist indefinitely.

Despite these challenges and difficulties, women in professional occupations have managed to enter previously male-dominated fields in ever-increasing numbers (England 2010; Mandel 2012; Charles and Grusky 2004; Cotter, Hermsen and Vanneman 2004). In the next section, this paper considers why women in blue-collar occupations have not followed suit. 


\section{WOMEN IN BLUE-COLLAR OCCUPATIONS: INDIVIDUAL AND STRUCTURAL CONSTRAINTS TO INTEGRATION}

Few studies have concentrated on women crossing the gender boundaries of blue-collar trades such as carpentry or mechanics. This topic deserves further investigation because it may be more difficult for women to secure and keep these male-dominated blue-collar jobs than is the case with women entering male-dominated professional occupations (Bergmann 2011; O’Farrel 1999).

\section{Individual Determinants of Segregation}

Paula England (2010) has thoroughly examined this problem by focusing on women's mobility aspirations. Her argument is structured around two contentions. First, she draws on Charles and Bradly's work (2009) to claim that people aspire to move up in society relative to a reference group from the previous generation of the same class and gender. Otherwise put, women might take their mothers, or perhaps other women with comparable educational backgrounds but a decade or so older than themselves, as their referent. England's second argument is that people have a strong tendency to work in occupations that are traditional for one's sex. This choice stems from robust and widespread gender essentialism, the notion that men and women are innately different (Charles 2011; Ridgeway 2009). Breaking gender boundaries thus carries a high social cost, and women are willing to challenge gender essentialism only when doing so is the one path to upward mobility.

England's argument implies that women enter male jobs solely if they are unable to find female-dominated jobs that offer a higher status than those held by women in the previous generation. This would explain the desegregation gap between professional and blue- 
collar fields. At the higher levels of the occupational hierarchy, there are fewer, if any, female-dominated professional career paths to pursue. Therefore, women had no choice but to cross gender barriers. Women from working-class families, however, can fulfill their aspirations to higher status and better pay vis-à-vis their reference group and avoid the costs of transgressing gender boundaries. They accomplish this by becoming pinkcollar workers (e.g. nurses, secretaries, or retail clerks) instead of moving into typically male-dominated blue-collar jobs. This form of upward mobility leads to persistent occupational segregation.

England's explanation has been challenged. Critics contend that most of the mothers of women who entered high-status male-dominated occupations over the last decades were not themselves employed in high-status female occupations. In fact, many of them were housewives, which shakes the foundation of England's argument (Bergmann 2011). Furthermore, feminists have fiercely accused England of gender essentialism and argued that there is nothing inherently female about typical "female" work (Reskin and Maroto 2011). Also complicating England's claim is that choosing gender-segregated jobs is economically irrational. Pace England and human capital scholars, there is no reason to expect that working-class women would be less rational economic actors than their male counterparts when it comes to looking for the best-paying jobs (Reskin and Maroto 2011). Finally, it has been argued that England's thesis is inconsistent with research on intergenerational mobility (McCall 2011). If the upward mobility project were gendered in the sense proposed by England, a father's career path would predict his son's and a mother's career path her daughter's. Empirical research shows, however, that the experiences and resources (Beller 2009) of both parents are significant to children's class outcomes. On this issue, England agrees on the importance of cumulative class resources 
in explaining children's class status, yet she maintains that these resources are irrelevant in predicting the sex composition of the occupations in which women end up working.

\section{Structural Constraints}

Scholars contesting England's theory have proposed alternative explanations for occupational segregation, including one in which segregation stems from an employer's personnel practices rather than from a woman's personal career choices. These scholars attribute the persistent segregation in blue-collar occupations to a lack of formal education and training opportunities for women entering male-dominated blue-collar trades (Bergmann 2011).

The relative value of academic and training credentials distinguishes the hiring practices in the professional and blue-collar fields. Well-educated women have used their credentials to enter into traditionally male, professional occupations. However, on-thejob training — rather than educational attainment — counts most in the blue-collar sector (Bergmann 2011; Reskin and Maroto 2011). Male workers, who play a significant role in the training of new entrants, often resent the presence of women in the workforce and pressure managers to favor men over women in the hiring process (Bergmann 2011; Roos and Reskin 1984). In the absence of codified and enforced hiring practices, managerial discretion opens the door to homophile behavior, cognitive biases (Reskin 2000), and the perpetuation of stereotypes (Heilman 2011; Roth 2006; Torre 2014).

Optimistic voices contend that discrimination at the hiring stage could be avoided by instituting a formal training system for blue-collar occupations. Just as in the professional sector, applicants would master the basic skills required before applying for a job, and this vocational training would theoretically remove some degree of arbitrariness from the 
selection process. It would also reduce sex segregation, both by regulating how people learn about and apply for jobs and by setting relevant criteria for choosing among applicants (Bergmann 2011; Reskin and Maroto 2011). Yet there are reasons to believe that the socialization forces discussed in the previous section might hinder the potential impact of vocational training on integration. Gendered socialization, coupled with the necessity of choosing an occupational track early on in one's vocational education, might push women to self-select into specific VET fields (Reisel, Hegna and Imdorf 2016; Imdorf and Hupka-Brunner 2015; Buchmann and Charles 1995). For example, women are more likely than men to prefer classroom-based training to apprenticeships or employer-mediated training, presumably to avoid gender-based employer discrimination (Estévez-Abe 2006). Under these circumstances, VET systems - if not carefully designed with these concerns in mind-could end up working as gendered "sorting machines" rather than as instruments promoting equality (Reisel et al. 2016; Smyth and Steinmetz 2008).

Some work has been done on VET systems, mostly comprised of empirical, singlecountry studies. One obstacle to performing a more comprehensive analysis is that national systems of vocational education and training are very diverse. For example, countries might vary in the range of occupations for which one can receive vocational education (Verdier 2013). Also, while dual vocational training programs-which combine one or two days a week at a vocational school with apprenticeships in a company-have long been common in German-speaking countries (i.e., Germany, Austria, and Switzerland), other countries like Spain have only recently adopted them (OECD 2011). Given that country differences might be reflected both in labor market structures and in cultural attitudes (e.g., gendered occupational aspirations), systematic 
research is still needed to adequately assess how individual characteristics and structural factors impact the lack of integration segregation in blue-collar occupations.

\section{Piecing Together the Story}

The present study sheds new light on gender segregation in several ways, first and foremost by focusing on women crossing gender boundaries in blue-collar, rather than professional, occupations. Second, it takes on England's call (2011) for new research that considers not only individual but also structural factors that might have been impeding women's entry into low-status male-dominated occupations. Here, I analyze how women's employment in blue-collar occupations varies in countries with different levels of VET enrollment - and how these programs might affect cultural attitudes. I also examine the relevance of parental background (paternal and maternal education level and working status) on the type and sex composition of the occupation in which women and men end up working. Admittedly, available data do not allow us to identify the specific social mechanism underlying the link between parental background and occupation, but this analysis is the first step in demonstrating the validity of individual-based arguments.

\section{DATA AND METHODS}

I use a cumulative data file for Rounds 4 to 8 (fielded in 2008, 2010, 2012, 2014, and 2016) of the European Social Survey (ESS). The cumulative data set contains information for 95,867 working individuals in 25 countries. For some countries, data are not available for all years (see Appendix A for description). 
Appended to the ESS data is the sex composition of three-digit Labour Force Survey (LFS) occupations, estimated by country and year. LFS is the best source of occupational data for estimates of segregation in European countries, as it provides large sample sizes broken down by detailed occupational codes (three-digit level). This detailed coding is a vital feature since having fewer job categories would result in certain male-dominated and female-dominated occupations being grouped into larger, apparently sex-neutral categories (Blau et al. 2013; Jacobs 1993).

\section{The Dependent Variables}

The multivariate analysis involves two steps. First, I estimate men's and women's probability of being employed in a blue-collar occupation. The variable Blue-collar covers workers in manual labor, including jobs in Craft and related occupations, Plant and machine operators and assemblers, and Other elementary occupations. An individual is coded " 1 " if working in a blue-collar occupation and " 0 " if employed in service, clerical, or professional/managerial occupations). ${ }^{4}$

In the second step, I restrict the analysis to those employed in the blue-collar sector and split the sample by the sex composition of each occupation. I define an occupation as male-dominated when the female presence is below 33.3 percent and female-dominated when the female presence is above 66.6 percent. The rest of the jobs are considered "neutral." The dependent variable Male-dominated blue-collar occupation has a score of " 1 " when the person is employed in a male-dominated blue-collar occupation, and a score of " 0 " if employed in a female-dominated, or neutral, blue-collar occupation.

The chosen 33.3 percent threshold for male- and female-dominated occupations is similar to those used in previous research (Jacobs 1989; Torre 2014) but is certainly 
arbitrary. The results below, however, are robust to changes in these cutoff points (e.g., a 40 or 45 percent threshold for women in male-dominated occupations).

\section{Country-Level Covariates}

The most relevant country-level variable for the purposes of this article is Vocational education and training (VET). This variable is crucial for evaluating how institutionalized formal training affects variation in male and female representation in blue-collar occupations. VET measures the proportion of students enrolled in vocational education and training relative to the proportion of students enrolled in general academic programs, thus capturing the relative importance of vocational education in the given country's education system in a particular year.

The upper plot in Figure 1 reveals wide variation in average levels of VET enrollment across countries. ${ }^{5}$ At one extreme, we find Cyprus, where VET is almost nonexistent, and at the other extreme the Czech Republic and Austria, where the VET enrollment rate is 57 percent and 60 percent, respectively. ${ }^{6}$ The bottom plot shows that, regardless of the size of the programs, female and male enrollment in VET is quite similar across countries. Hence, results suggest that differences in the gender composition of blue-collar occupations across countries cannot be attributed to differences in gender participation in vocational training.

(Figure 1 about here)

Other factors could be at play; for example, it could be argued that working-class women do not enter blue-collar occupations because those job sectors are shrinking in many countries (MacCall 2011). To account for the structural constraints of occupational demand, the analysis controls for the Size of the blue-collar sector, the proportion of 
working people employed in the blue-collar sector in a particular year. Similarly, the variable Size of the male-dominated blue-collar sector measures the relative size of the male blue-collar occupations where men make up more than two-thirds of the workforce. As observed in Figure 2, employment in the blue-collar sector varies significantly across countries, ranging from 20 percent in the Netherlands to 47 percent in Hungary. Interestingly, the size of the male-dominated blue-collar field does not grow linearly with that of the blue-collar sector. In some nations-the Nordic Countries (Norway, 75 percent; Sweden, 77 percent; Denmark, 72 percent) and Germany (70 percent)—maledominated occupations make up more than two-thirds of the blue-collar sector. In other countries such as Portugal and Lithuania, male-dominated occupations represent only 40 percent and 50 percent of the blue-collar sector, respectively.

(Figure 2 about here)

\section{Individual-Level Covariates}

To measure the impact of the previous generation on respondents' occupational choices, I estimate statistical models that include parental education and working status as independent variables. The variable Mother's low level of education scores " 1 " when the respondent's mother has lower secondary or less than lower secondary education, and "0" otherwise. The variable Mother's working status reflects the respondent's mother's employment status when the respondent was 14 years old. It is coded " 0 " if the respondent's mother was unemployed, "1" if the mother was employed in a blue-collar occupation, and " 2 " if she was employed in any other than a blue-collar occupation. The coding for the father-related variables follows the same pattern. 
The models below also include several control variables: age, education, marital status, children living in the household, single parenting, and origin country. I operationalize the respondents" education levels through a dummy variable, where "1" denotes low education (lower secondary or less than lower secondary). The variable Children in the household scores " 1 " for those having children living in the parental house and "0" otherwise. Marital status is operationalized through the dummy variable Single, coded as " 1 " when the person is single and "0" otherwise. Single parenting, an interaction term between the variables Having children in the household and Single, aims to capture whether women who support families are more likely to seek better paid, male-dominated jobs (Glauber 2011; Padavic 1992, Glass 1990). Finally, the variable Native scores "1" for those born in the country and " 0 " for those who are foreign-born. This variable allows me to determine whether the native and foreign-born populations display different propensities to be employed in the blue-collar sector (Lancee 2016). Appendix B describes the variables included in the analyses by country.

\section{Analytical Strategy}

The primary goal of this article is to explore how the probability of being employed in blue-collar occupations varies across countries. As describe above, data are structured in hierarchically nested groups: individuals on the first level, countries on the second. As country membership may have an effect on individual's professional outcomes, it would be problematic to analyze all individuals while disregarding the countries where they work in. To address this critical issue, I estimate a two-level random intercept logit model with country-level predictors, which allow to capture that variation (Snijders and Bosker 2011). The dependent variable is related to the covariate vectors by a logistic regression equation: 


$$
\begin{gathered}
\log \left(\frac{\operatorname{Pr}\left(y_{i j}=1\right)}{1-\operatorname{Pr}\left(y_{i j}=1\right)}\right)=\beta_{0}+\beta_{1} x_{i j}+u_{j} \\
u_{j} \sim N\left(0, \sigma^{2}\right)
\end{gathered}
$$

$\beta_{0}$ is the log-odds that $\mathrm{y}=1$ when $x=0$ and $u=0$, and $\beta_{1}$ is effect on log-odds of one unit increase in $x$ for individuals in same group. The random part of the model is captured by $u_{\mathrm{j}}$, which measures the effect of being in country $\mathrm{j}$ on the log-odds that $\mathrm{y}=1$ (level 2 residual). Finally, $\sigma 2$ is the variance of the level 2 residual.

The final working sample includes respondents between 16 and 65 years old. It could be argued that this sample poses a problem because the influence of the education system on occupational paths is likely to be stronger for those who have been full-time students more recently (Smyth and Steinmetz 2016). I have thus conducted supplemental analyses, found in Appendix C, for individuals who are younger than 35. The findings remain consistent when considering this younger population.

I also run separate models for women and men, allowing me to assess whether individualand country-level variables affect men and women differently. Finally, as suggested by Mood (2009), I calculate marginal effects to help interpret the substantive effects of the coefficients.

\section{MEN AND WOMEN IN THE BLUE-COLLAR SECTOR: DESCRIPTIVE OVERVIEW}

On average, about 34 percent of the total working population are in blue-collar occupations. Of these workers, 61.5 percent are in male-dominated occupations, namely 
"Truck and lorry drivers" (7.24 percent); "Car, taxi, and van drivers" (5.44 percent); "Motor vehicle mechanics and repairers" (4.56 percent); "Bricklayers and related workers" (3.83 percent); "Carpenters and joiners" (3.74 percent); and "Plumbers and pipe fitters" (2.67 percent). Twenty-seven percent of the blue-collar workforce are in occupations where women constitute a majority; of these workers, 25.39 percent are "Cleaners and helpers in offices, hotels, etc.," and 9.02 percent are "Domestic cleaners and helpers" (9.02 percent). The remaining 11 percent of blue-collar workers are in gender-neutral occupations, including "Manufacturing laborer not elsewhere classified" (11.41 percent); “Garden and horticultural laborers" (6.53 percent); "Food and related products machine operators" (5.41 percent); and "Shelf fillers" (4.39 percent).

The results in Table 1 indicate that when comparing occupational groups, the masculinization of typically male-dominated jobs is significantly higher in blue-collar occupations (8.7 men for every woman) than in managerial and professional occupations (2.6 men for every woman) and service and clerical occupations (3 men for every woman). Interestingly, this is not the case in female-dominated occupations, where the sex ratio is pretty similar across the blue-, pink-, and white-collar sectors.

(Table 1 about here)

Figure 3 below displays the distribution of men and women employed in blue-collar trades in all the countries in the sample. The left plot shows all blue-collar jobs. As seen in the graph, male representation surpasses female representation in every country. The gender gap, however, varies significantly among countries. The largest spreads are found in the Nordic countries (Norway, Denmark, Sweden) and Germany, with an almost 60 percentage-point difference in male and female representation. On the other extreme is 
Portugal, where there is a similar proportion of males and female employees in the bluecollar sector.

The right plot displays male-dominated blue-collar occupations. Once we limit the sample to these male-dominated trades, variation in female representation rates decreases drastically. Austria and Hungary show a relatively higher prevalence of women in the male-dominated field (about 15 percent), whereas Portugal and Cyprus display participation rates below 5 percent. Because they are universally low, these rates contradict the proposition that women in the working and middle classes are not entering male blue-collar jobs because of the sector's contraction (McCall 2011). On the contrary, the dearth of women in male-dominated blue-collar jobs is a general trend across all countries - independent of sector size.

(Figure 3 about here)

This trend is certainly puzzling given the strong economic incentives that both men and women have to work in male-dominated jobs. Figure 4 below reveals that the average pay in male-dominated blue-collar occupations is indeed consistently higher than in equivalent female-dominated occupations in all twenty countries for which salary information is available. The smallest gap is observed in Bulgaria, where those working in male-dominated blue-collar occupations earn 1.6 times more than employees in typically female jobs. In Germany and Cyprus, this multiple increases to 2. 3, and 2.9, respectively.

(Figure 4 about here)

Owing to these pay gaps and cultural pressures, men have few financial or social reasons to choose female-dominated jobs. For women, on the other hand, accessing male- 
dominated fields seems to be the logical choice for economic advancement (Jacobs 1993). And yet, women are being excluded from pursuing other career paths. The next section takes a more detailed look at the determinants of employment in blue-collars occupations.

\section{MULTIVARIATE ANALYSIS}

This article primarily seeks to explain how the probability of men and women being employed in the blue-collar sector varies with their background and the prevalence of vocational training in their country. To this end, this paper uses two-level, random intercept logit models whose coefficients are displayed in Table 2. In these models, the probability of the dependent variables may vary on average across countries, but all of the effects of the predictor and control variables are equalized across countries. $\mathrm{M}_{01-04}$ (empty models) indicate that there is significant between-country variation in occupation type when no individual-level variables are included in the model. Models $\mathbf{M}_{1}$ and $\mathbf{M}_{2}$ examine the probability of a woman or a man being employed in a blue-collar occupation versus in service, clerical or professional occupations. Finally, Models $\mathrm{M}_{3}$ and $\mathrm{M}_{4}$ estimate the likelihood of being employed in a male dominated blue-collar jobs, among those men and women working in the blue-collar field only ${ }^{7}$.

(Table 2 about here)

Estimates in $\mathrm{M}_{1}$ indicate that countries with a higher proportion of students enrolled in VET relative to general academic programs do show a greater presence of women in bluecollar trades. However, unlike Bergmann's (2011) expectation, VET does not affect the probability of a woman being employed in traditionally male blue-collar jobs $\left(\mathrm{M}_{3}\right)$. These findings are most clearly displayed in Figure 5, which charts the marginal effects of VET 
levels. The graph on the left shows the results for all blue-collar occupations-without taking into consideration the sex composition of the occupation-and the one on the right for male blue-collar occupations only. In both cases, the graphs depict the lowest predicted probabilities of being employed in blue-collar trades ${ }^{8}$. The unbroken and dashed lines represent the respective likelihoods of women and men to be employed in the given occupational category. One sees that the probability of being employed in a blue-collar job, whether a male-dominated one or not, is always higher among men than women. More specifically, the estimated representation rate for men increases from 21 percent in countries where VET is lowest to 42 percent in countries where it is highest. For women, it rises from 7 percent to 15 percent.

(Figure 5 about here)

VET's lack of impact becomes evident when we focus on male-dominated jobs. Here, the figure reveals a flat participation rate for women, with variations of less than 1 percent between countries with the lowest and the highest rates of VET enrollment. As for men, their participation in male-dominated jobs is slightly lower ( 7 percent) in countries with higher levels of formal training. The effect, although statistically significant, is not very notable. Overall, these findings suggest that women's representation in male blue-collar occupations does not depend on VET. Rather, the results indicate the opposite: vocational education and training systems reproduce segregation in the job market (Reisel et al. 2016; Smyth and Steinmetz 2008; Estévez-Abe 2006). This finding holds true after controlling for the size of the blue-collar sector. A larger sector significantly increases the chances of becoming a blue-collar worker but has little effect on the distribution of men and women into gender-typed occupations. 
The second block of variables in Table 2 includes parental background characteristics. It shows that men and women, whose mothers had lower levels of educational qualifications, are significantly more likely to work in blue-collar occupations than in service, clerical, or professional occupations. The same holds true for the respondents' fathers' education. Somewhat different is the effect of parental working status. On the one hand, both father's and mother's high-status position reduce the likelihood of being a blue-collar worker. On the other hand, blue-collar mothers influence daughters (positively) but has no effect on sons, while blue-collar fathers influence sons (positively) but has no effect on daughters. These results only partially corroborate previous research arguing that both parents' backgrounds influence their children's career path (McCall 2011; Beller 2009). Furthermore, parental background has little effect on the probability of men and women working in typically male occupations. Model $\mathrm{M}_{3}$ in Table 2 shows that only having a mother in a higher-status position (i.e., professional or service) increases the chances of women working in a typically male job. In other words, female descendants from high-status mothers are less likely to work in the blue-collar sectors, but when they do, they are more likely to be employed in the male field than are women from working-class homes. Furthermore, the data reveal that women tend to remain in female-dominated blue-collar occupations regardless of their fathers' educational and employment background. Only for men does paternal working status predict employment in male-dominated blue-collar occupations $\left(\mathrm{M}_{4}\right)$.

Figure 6 compares the effect that mothers and fathers have on their children's professional attainment. The upper plots refer to women (left) and men (right) employed in the bluecollar sector. Both parents' education have a roughly similar impact on their children. Interestingly, their influence appears to be relatively more important in accounting for male professional outcomes. Thus, mother's education scores 0.27 and father's 0.23 in 
the case of daughters. For sons, the values increase to 0.61 and 0.62 , respectively. As discussed above, blue-collar status only influences significantly on children of their own sex. Yet again, mother's effect on daughters is lower $(0.27)$ than father's effect on sons (0.8). The bottom plots display the results for male-dominated blue-collar jobs. As pointed out above, having a mother in a high-status position is the best predictor for women entering a typically male job. The opposite holds true with men, for whom the father's working status is the strongest predictor. Thus, parental influence appears to be somewhat gendered, as family members of one's sex are relatively more important. These results suggest that it may be difficult to transgress occupational gender boundaries, corroborating England's claim that cumulative class resources are not good predictors of the sex composition of the occupations in which women find themselves (England 2011).

(Figure 6 about here)

Turning to control variables, Table 2 shows that lower levels of educational qualifications increases the probability of men and women working in the blue-collar sector but reduces the chances of working in male-dominated occupations. Results suggest that, within the blue-collar field, the best remunerated (and usually male-dominated) jobs are reserved for the best-educated people. Being single is not associated with one's likelihood of working in the blue-collar sector (except for men in typically male jobs), nor is living with children in the household (except for men in general blue-collar jobs). Being a single parent, however, is a strong predictor of outcomes, the only exception being women in maledominated occupations. This is certainly paradoxical, since the higher pay and better benefits of male-dominated jobs might be more attractive to women who are supporting families (Glauber 2011; Padavic 1992; Glass 1990). Finally, results are consistent with previous research on immigration. Regardless of the sex of the individual, non-native 
people are more likely to be employed in blue-collar occupations than are native individuals. Moreover, they are more likely to be concentrated in the neutral of femaledominated sector — where the pay and benefits are often lower — corroborating the notion that immigrants face substantial disadvantages vis-à-vis the native-born population (Lancee, 2016).

Finally, the last section addresses random effects. The random intercept conveys the combined effect of all omitted subject-specific covariates that make some subjects more likely to be employed in (male) blue-collar jobs than others. Supplemental analyses for individuals who are younger than 35 are provided in Appendix C. The findings remain consistent when considering this younger population, but two notable differences emerge. First, being a young single mother increases the chances of working in a male occupation, as anticipated in prior research (Glauber 2011; Padavic 1992; Glass 1990). Second, parent's working status becomes less relevant for people under 35 entering maledominated jobs. These results might indicate that the transmission of social class has attenuated over recent decades, particularly among women, in line with the trends documented in several countries (Breen, 2005; Jonsson and Mills, 1993).

\section{DISCUSSION}

This study finds that across countries, female participation in male blue-collar sectors does not vary with levels of VET. Unlike with higher education and professional training, VET systems have not been successful integrating male occupations. At the individual level, the analysis shows a high degree of intergenerational class reproduction within the blue-collar sector: people whose parents were unemployed, not well-educated, or held a blue-collar job are significantly more likely to work in the blue-collar sector than in other higher-status occupations. Consistent with England's expectations, however, cumulative 
class resources from either parent do not explain the gender composition of the occupation in which children end up working. Women largely remain in gendered careers regardless of their family background, the only exception being if they have a mother in a highstatus occupation. Daughters from high-status women have moved into male occupations with greater frequency. It could be that traditionally female professions (teaching, nursing, social work) have been unable to absorb the increasing number of new female college graduates, pushing some into male professions - not to achieve upward mobility but rather to avoid downward class mobility (England 2011).

Overall, the results are in line with recent evidence from different countries showing that VET actually segregate women and men by field of study, and later by occupation, even more than the general education system does (Smyth and Steinmetz 2016; Reisel et al. 2016; Imdorf and Hupka-Brunner 2015). Higher education in general, and access to law school, medical school, and other credentialing opportunities, were essential prerequisite for the considerable progress that women have made in these fields (Boulis and Jacobs 2008; Epstein 1993; Solomon 1985). Fighting for women's access to typically male bluecollar occupations, however, neither benefitted from a similar degree of political pressure nor received as much cultural support. Indeed, the findings in this study point to the existence of a societal gendering mechanism that entrenches horizontal segregation in the blue-collar sector more firmly than in professional occupations. In part, this could be because gender-egalitarian attitudes are more prevalent among people with higher degrees of educational attainment (Cotter et al. 2011). Empirical evidence shows an increase in liberal attitudes throughout the 1970s and 1980s among all workers, followed by a downturn in the 1990 s and a rebound after 2000 , but this late bounce in egalitarian thinking has been more marked among better-educated individuals (Cotter et al. 2011). Consequently, socialization into traditional gendered roles-both at home and the 
school—will be markedly higher among working classes, driving men and women to choose gendered paths (Polavieja and Platt 2014). Thus, while the gender revolution has generated important reductions in vertical gender inequality over the past thirty years (Charles and Grusky 2004), VET systems have failed to integrate the blue-collar sector, and many occupational ghettoes stubbornly persist in low-status, female-dominated fields.

The entry of women into previously male-dominated professions requires, then, policies that operate at earlier stages both at the structural and at the individual level. Combatting gendered socialization in the family and at school will eventually increase the effectiveness of VET systems in reducing sex segregation in the workplace. Thus, it may be useful to think of training programs less as an isolated variable and more as part of a broader set of political and cultural changes promoting women's access to maledominated blue-collar jobs.

The combination of individual and structural indicators in this work provides fresh insights into the segregation of blue-collar occupations and represents a necessary first step in laying bare the mechanisms of segregation. The empirical findings obtained from this study raise new questions that require further research. Detailed data on VET domains, the sex composition of parental occupation, gender-role attitudes and workplace social networks will be needed to advance our understanding of the social mechanisms operating behind the persistently high levels of segregation in the blue-collar trades.

\section{ENDNOTES}


1. Austria (AT), Belgium (BE), Bulgaria (BG), Czech Republic (CH), Croatia (HR), Cyprus (CY), Germany (DE), Denmark (DK), Estonia (EE), Spain (ES), Finland (FI), France (FR), Greece (GR), Great Britain (UK), Hungary (HU), Ireland (IE), Lithuania (LT), The Netherlands (NL), Norway (NO), Poland (PL), Portugal (PT), Sweden (SE), Slovenia (SL), Slovakia (SK), Switzerland (CZ).

2. See https://www.onetonline.org/.

3. It is important not to confuse female-dominated blue-collar jobs with pink-collar jobs. While both are feminized, the two kinds of jobs differ significantly, not only in terms of prerequisite education and training but also in pay and working conditions.

4. Occupations in Agriculture, Forestry and Fisheries, and Armed Forces are excluded from the sample.

5. Unfortunately, the US is not included in the ESS, and thus the level of vocational training in the US cannot be directly compared to the European systems using these data. The complex, multi-track vocational training systems in the US further complicates the task of ranking the US against other countries. Observers such as James Rosenbaum, however, have suggested that formal vocational training in the US lags behind that in other countries.

6. In some countries, the range of occupations for which one can get vocational education is narrow, while in other countries it is wider (Verdier 2013). Unfortunately, the available data do not allow us to control for this contrast. Smyth and Steinmetz (2015), however, found that VET system characteristics make relatively little difference when explaining occupational outcomes among women (Smyth and Steinmetz 2016). 
7. In additional analysis (not shown), I have tested differences among men and women. Results indicate that the gender difference is statistically different from 0 at the 0.001 level, both in blue-collar and male-dominated blue-collar occupations.

8. Dummy variables (except Single) are set at "0," and continuous variables are centered at their mean.

\section{REFERENCES}

Beller, Emily. 2009. "Bringing intergenerational mobility research into the twentieth-first century: Why mothers matter." American Sociological Review 74:507-528.

Bergmann, Barbara R. 2011. "Sex segregation in the blue-collar occupations: Women's choices or unremedied discrimination? Comment on England.” Gender and Society 25: 1: 88-93.

Boulis, Ann and Jerry A. Jacobs. 2008. "The changing face of medicine". Ithaca, NY: Cornell University Press.

Breen, Richard (ed.). 2005, Social Mobility in Europe. Oxford University Press.

Buchmann, Marlis and Maria Charles. (1995). "Organizational and institutional factors in the process of gender stratification: Comparing social arrangements in six European countries. ” International Journal of Sociology, 25(2):66-95.

Charles, Maria, and David B. Grusky. 2004. Occupational Ghettos: The worldwide segregation of women and men. Stanford, CA: Stanford University Press.

Charles, Maria, and Karen Bradley. 2009. "Indulging our gendered selves: Sex segregation by field of study in 44 countries.” American Journal of Sociology 114:924-76.

Charles, Maria. 2011. “A world of difference: International trends in women's economic status." Annual Review of Sociology 37:355-371. 
Cotter, David A., Joan M. Hermsen, and Reeve Vanneman. 2004. Gender Inequality at Work. New York: Russell Sage Foundation.

Cotter, David A., Joan M. Hermsen, and Reeve Vanneman. 2011. "The End of the Gender Revolution? Gender Role Attitudes from 1977 to 2008." The American Journal of Sociology 117: 259-289.

Davis, Shannon N. and Theodore N. Greenstein. 2009. Gender ideology: Components, predictors, and consequences. Annual Review of Sociology 35:87-105.

England, Paula, Melissa S. Herbert, Barbara S. Kilbourne, Lory L. Reid, and Lory M. Megdal. 1994. "The Gendered Valuation of Occupations and Skills: Earnings in 1980 Census Occupations.” Social Forces 73(1):65-100.

England, Paula. 2010. "The gender revolution. Uneven and Stalled." Gender \& Society 24(2):149-166.

England, Paula. 2011. "Reassessing the uneven gender revolution." Gender \& Society 25(1):113-123.

Epstein, Cynthia Fuchs. 1993. "Women in law”. Urbana: University of Illinois Press

Estévez-Abe, Margarita. 2006. "Gendering the varieties of capitalism: A study of occupational segregation by sex in advanced industrial societies." World Politics 59(1):142-175

Filer, Randall K. 1985. Male-female wage differences: The importance of compensating differentials. Industrial and Labor Relations Review 38 (3): 426-37

Filer, Randall K. 1989. "Occupational segregation, compensating differentials and comparable worth.” In R. Michael, H. Hartmann and B. O'Farrel (Eds.), Pay equity: Empirical inquiries: pp. 153-170. Washington DC: National Academy Press. 
Glass, J. 1990. "The Effect of Occupational Segregation on Working Conditions." Social Forces 68(3): 779-796.

Glauber, Rebecca. 2011. "Limited Access: gender, occupational composition, and flexible work scheduling." The Sociological Quarterly 52:471-494.

Heilman, Madeline E. 2001. "Description and prescription: How gender stereotypes prevent women's ascent up the organizational ladder.” Journal of Social Issues 57:657-74.

Howe, Louis Kapp. 1977. "Pink Collar Workers: Inside the World of Women's Work" Putnam Pub Group

Imdorf, Christian, and Hupka-Brunner, Sandra. 2015. "Gender differences at labor market entry in Switzerland.” In Hans-Peter Blossfeld, Jan Skopek, Moris Triventi, and Sandra Buchholz (Eds.), Gender, education and employment: An international comparison of school-to-work transitions, 260-279. Cheltenham, UK: Edward Elgar.

Jacobs, Jerry A. 1989. Revolving doors. Sex segregation and women's careers. Stanford, California: Stanford University Press.

Jacobs, Jerry A. 1993. "Men in female-dominated fields. Trends and turnover." Pp. 49-63 in Doing women's work: Men in non-traditional occupations., edited by Christine L. Williams. Newbury Park, CA: Sage.

Jacobs, Jerry A. 1993. Theoretical and Measurement Issues in the Study of Sex Segregation in the Workplace: Research Note. European Sociological Review, 9(3): 325-330

Jacobs, Jerry A. and Ronnie Steinberg. 1990. "Compensating differentials and the malefemale wage gap: Evidence from the New York state comparable worth study." Social Forces 69:2: 439-468.

Jonsson, Jan O. and Colin Mills. 1993. "Social Mobility in the 1970s and 1980s: A Study of Men and Women in England and Sweden.” European Sociological Review 9:229_ 48. 
Lancee, Bram. 2016. "The negative side effects of vocational education: A cross-national analysis of the relative unemployment risk of young non-western immigrants in Europe." American Behavioral Scientist 60(5-6): 659-679.

Levanon, Asaf, Paula England, and Paul D. Allison. 2009. “Occupational feminization and pay: Assessing causal dynamics using 1950-2000 census data.” Social Forces 88: 497-517.

Liza Reisel, Kristinn Hegna, and Christian Imdorf. 2016. "Gender segregation in Vocational Education: Introduction." In Gender Segregation in Vocational Education. Published online: 18 Nov 2015; 1-22.

Lupton, Ben. 2000. "Maintaining Masculinity: Men Who do 'Women's Work."” British Journal of Management, 11:33-48.

MacCall, Leslie. 2011. Women and Men as Class and Race Actors. Gender and Society 25:94-100

Mandel, Hadas. 2012. "Occupational mobility of American women: Compositional and structural changes, 1980-2007." Research in Social Stratification and Mobility 30:516.

McCall, Leslie. 2011. "Women and men as class and race actors: Comment on England." Gender \& Society 25(1):94-100.

Mincer, Jacob, and Solomon Polachek. 1974. Family investments in human capital: Earnings of women. Journal of Political Economy 82 (2): 76-108.

Mood, Carina. 2009. "Logistic Regression: why we cannot do what we think we can do, and what we can do about it." European Sociological Review 26:1:67-82.

O'Farrel, Brigid. 1999. Women in blue collar and related occupations at the end of the millennium. The Quarterly Reivew of Economics and Finance 39:699-722 
OECD (2011). Learning for Jobs. OECD reviews of vocational education and training, http://www.oecd.org/education/skills-beyond$\underline{\text { school/LearningForJobsPointersfor\%20PolicyDevelopment.pdf }}$

Padavic, Irene A. 1992. “White-Collar Work Values and Women's Interest in Blue-Collar. Gender and Society, 6(2):215-230

Polachek, Solomon. 1981. Occupational self-selection: A human capital approach to sex differences in occupational structure. The Review of Economics and Statistics 63 (1): $60-9$.

Polavieja, Jarvier G., and Lucinda Platt. 2014. Nurse of Mechanic? The Role of Parental Socialization and Children's Personality in the Formation of Sex-typed Occupational Aspirations. Social Forces 92(1):31-61

Reskin, Barbara F. and Michelle L. Maroto. 2011. "What trends? Whose choices? Comment on England." Gender \& Society 25(1):81-87.

Ridgeway, Cecilia L. 2009. "Framed before we know it: How gender shapes social relations." Gender \& Society 23:145-60.

Roos, Patricia, and Barbara F. Reskin. 1984. "Institutionalized barriers to sex integration in the workplace." In Sex segregation in the workplace, edited by Barbara Reskin, 23560. Washington, DC: National Academy Press.

Rosen, Sherwin. 1986. “The Theory of Equalizing Differences.” Pp 641-92 in Handbook of Labor Economics, edited by Orley Ashenfelter and Richard Layard. Elsevier.

Roth, Louise. 2006. Selling women short: Gender and money on Wall Street. Princeton, NJ: Princeton University Press.

Smith, Adam. [1776]1976. An inquiry into the Nature and Causes of the Wealth of Nations, edited by Edwin Cannan. University of Chicago Press. 
Smyth, Emer, and Stephanie Steinmetz. 2008. "Field of study and gender segregation in European labour markets." International Journal of Comparative Sociology 49(45): $257-281$

Smyth, Emer, and Stephanie Steinmetz. 2016. "Vocational Training and Gender Segregation Across Europe" in Gender Segregation in Vocational Education.” Published online: 18 Nov 2015; 53-81.

Snijders, Tom A.B., and Roel J. Bosker. 1999. Multilevel analysis. An introduction to basic and advanced multilevel modelling. Thousand Oaks, CA: Sage.

Solomon, Barbara M. 1985. "In the company of educated women: a history of women and higher education in America". New Haven: Yale University Press

Tam, Tony. 1997. Sex segregation and occupational gender inequality in the United States: Devaluation or specialized training. American Journal of Sociology 102 (6): 165292

Torre, Margarita. 2014. “The Scarring Effect of 'Women's Work': The Determinants of Women's Attrition from Male-dominated Occupations.” Social Forces 93(1):1-29

U.S. Bureau of Labor Statistics (2017). May 2017 National Occupational Employment and Wage Estimates United States, https://www.bls.gov/oes/current/oes_nat.htm

Verdier, Eric. 2013. "Lifelong learning regimes versus vocational education and training systems in Europe: The growing hybridization of national models." In A. Green, J. G. Janmaat, \& P. Mehaut (Eds.), The dynamics and social outcomes of education systems, 70-93. Houndmills: Palgrave Macmillan.

Williams, Christine L. 1995. Still a man's World: Men Who do “Women's Work.” Berkeley: University of California Press.

Williams, Christine L. 1993. "The Glass Escalator, Revisited: Gender Inequality in Neoliberal Times." Gender and Society 27:609-629. 
Table 1. Sex distribution by occupational category

\begin{tabular}{|c|c|c|c|c|c|}
\hline \multicolumn{6}{|c|}{ Blue-collar occupations } \\
\hline \multicolumn{2}{|c|}{$\begin{array}{l}\text { Male-dominated } \\
\text { (more than } 66 \% \text { men) }\end{array}$} & \multicolumn{2}{|c|}{$\begin{array}{c}\text { Neutral } \\
\text { (between 33\% and 66\% men) }\end{array}$} & \multicolumn{2}{|c|}{$\begin{array}{l}\text { Female-dominated } \\
\text { (less than } 33 \% \text { men) }\end{array}$} \\
\hline \multicolumn{2}{|c|}{61.49} & \multicolumn{2}{|c|}{11.18} & \multicolumn{2}{|c|}{27.33} \\
\hline Women & Men & Women & Men & Women & Men \\
\hline 10.37 & 89.63 & 54.6 & 45.4 & 83.42 & 16.58 \\
\hline
\end{tabular}

Pink-collar occupations

(Service, Clerical and Sales)

\begin{tabular}{|c|c|c|c|c|c|}
\hline \multicolumn{2}{|c|}{ Male-dominated } & \multicolumn{2}{|c|}{ Neutral } & \multicolumn{2}{|c|}{ Female-dominated } \\
\hline \multicolumn{2}{|c|}{10.22} & \multicolumn{2}{|c|}{9.66} & \multicolumn{2}{|c|}{80.11} \\
\hline Women & Men & Women & Men & Women & Men \\
\hline 24.53 & 75.47 & 58.12 & 41.88 & 80.89 & 19.91 \\
\hline
\end{tabular}

White-collar occupations

(Managers, Professionals and Technicians)

\begin{tabular}{cc|cc|cc}
\hline \multicolumn{2}{c|}{ Male-dominated } & \multicolumn{2}{c|}{ Neutral } & \multicolumn{2}{c}{ Female-dominated } \\
\hline \multicolumn{2}{c|}{37.44} & \multicolumn{2}{c|}{23.02} & \multicolumn{2}{c}{39.54} \\
\hline Women & Men & Women $\quad$ Men & Women & Men \\
\hline 27.49 & 72.51 & 50.50 & 49.50 & 77.32 & 22.68 \\
\hline \hline
\end{tabular}


Table 2. Multilevel Logistic Regression of employment in the blue-collar fields.

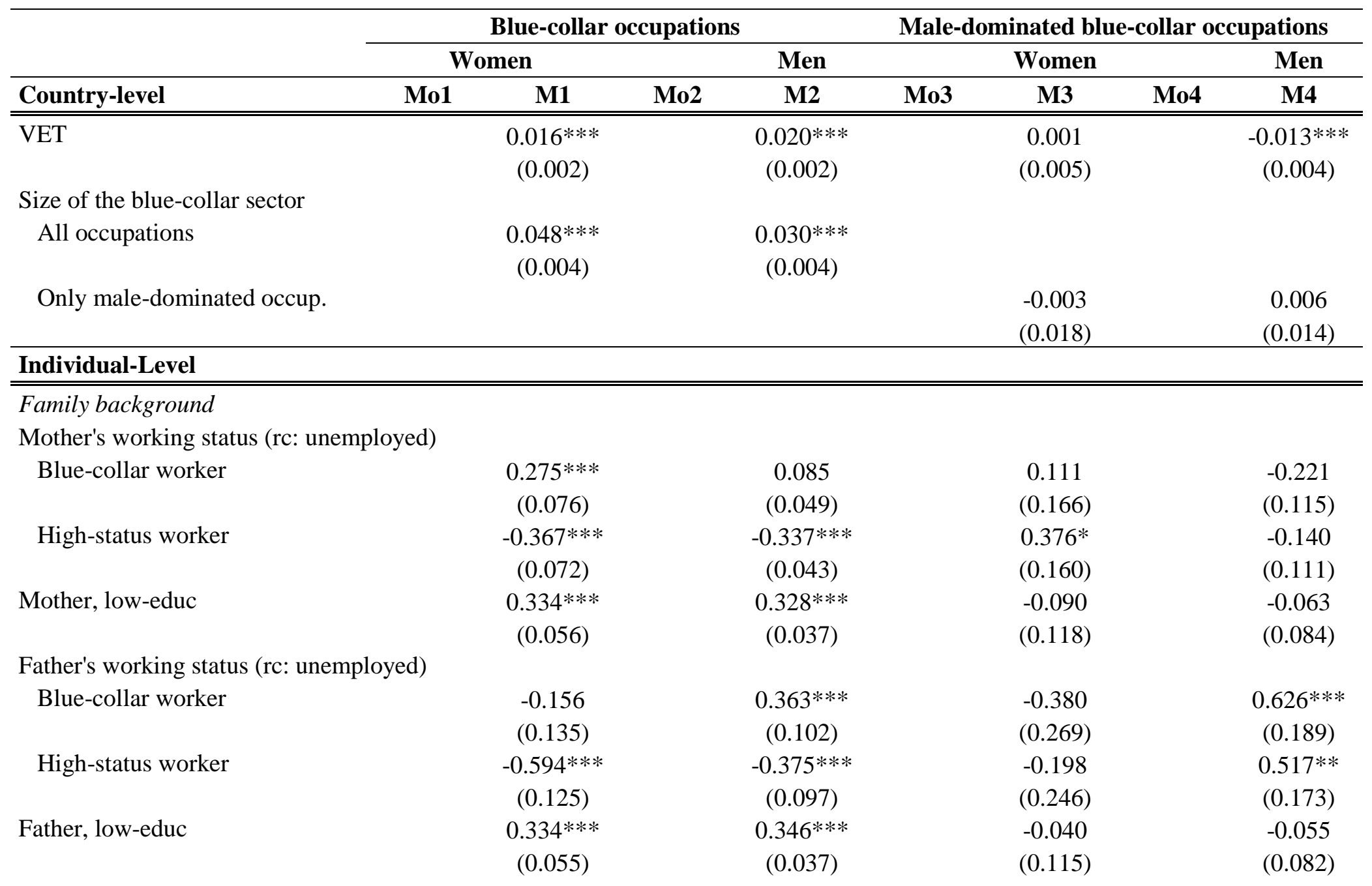


Control variables

\begin{tabular}{|c|c|c|c|c|c|c|c|c|}
\hline Age & & $\begin{array}{l}-0.002 \\
(0.002)\end{array}$ & & $\begin{array}{c}-0.016^{* * * *} \\
(0.001)\end{array}$ & & $\begin{array}{l}-0.003 \\
(0.004)\end{array}$ & & $\begin{array}{c}0.004 \\
(0.003)\end{array}$ \\
\hline Low-educ & & $\begin{array}{c}1.818 * * * \\
(0.057)\end{array}$ & & $\begin{array}{c}1.431 * * * \\
(0.045)\end{array}$ & & $\begin{array}{c}-0.381 * * * \\
(0.114)\end{array}$ & & $\begin{array}{c}-0.388 * * * \\
(0.081)\end{array}$ \\
\hline Single & & $\begin{array}{l}-0.088 \\
(0.075)\end{array}$ & & $\begin{array}{l}-0.014 \\
(0.044)\end{array}$ & & $\begin{array}{c}0.168 \\
(0.157)\end{array}$ & & $\begin{array}{c}-0.315 * * * \\
(0.095)\end{array}$ \\
\hline Children in the household & & $\begin{array}{c}0.017 \\
(0.049)\end{array}$ & & $\begin{array}{c}-0.172^{* * * *} \\
(0.033)\end{array}$ & & $\begin{array}{l}-0.116 \\
(0.106)\end{array}$ & & $\begin{array}{c}0.014 \\
(0.077)\end{array}$ \\
\hline Single parenting & & $\begin{array}{c}0.301^{* *} \\
(0.108)\end{array}$ & & $\begin{array}{c}0.339 * * * \\
(0.073)\end{array}$ & & $\begin{array}{c}0.098 \\
(0.220)\end{array}$ & & $\begin{array}{l}0.385^{*} \\
(0.168)\end{array}$ \\
\hline Native-born & & $\begin{array}{c}-1.027 * * * \\
(0.062)\end{array}$ & & $\begin{array}{c}-0.190 * * * * \\
(0.049)\end{array}$ & & $\begin{array}{c}0.418 * * \\
(0.130)\end{array}$ & & $\begin{array}{c}0.656 * * * \\
(0.095)\end{array}$ \\
\hline Intercept & $\begin{array}{c}-1.792 * * * * \\
(0.049)\end{array}$ & $\begin{array}{c}-3.449 * * * \\
(0.227)\end{array}$ & $\begin{array}{c}-0.436 * * * * \\
(0.039) \\
\end{array}$ & $\begin{array}{c}-1.749 * * * \\
(0.187)\end{array}$ & $\begin{array}{c}-1.228 * * * * \\
(0.066)\end{array}$ & $\begin{array}{c}-1.009 * \\
(0.496)\end{array}$ & $\begin{array}{c}1.929 * * * \\
(0.055)\end{array}$ & $\begin{array}{c}1.335^{* * * *} \\
(0.363) \\
\end{array}$ \\
\hline \multicolumn{9}{|l|}{ Ramdon Effects } \\
\hline sd (Intercept) & $\begin{array}{c}0.479 * * * \\
0.036 \\
\end{array}$ & $\begin{array}{c}0.261 * * * \\
(0.032) \\
\end{array}$ & $\begin{array}{c}0.391 * * * \\
(0.029) \\
\end{array}$ & $\begin{array}{c}0.290 * * * \\
(0.027) \\
\end{array}$ & $\begin{array}{c}0.587 * * * \\
(0.055) \\
\end{array}$ & $\begin{array}{c}0.524 * * * \\
(0.069) \\
\end{array}$ & $\begin{array}{c}0.503 * * * \\
(0.044) \\
\end{array}$ & $\begin{array}{c}0.446 * * * \\
(0.052) \\
\end{array}$ \\
\hline
\end{tabular}


F1. Vocational Training by country. Average values 2008-2016

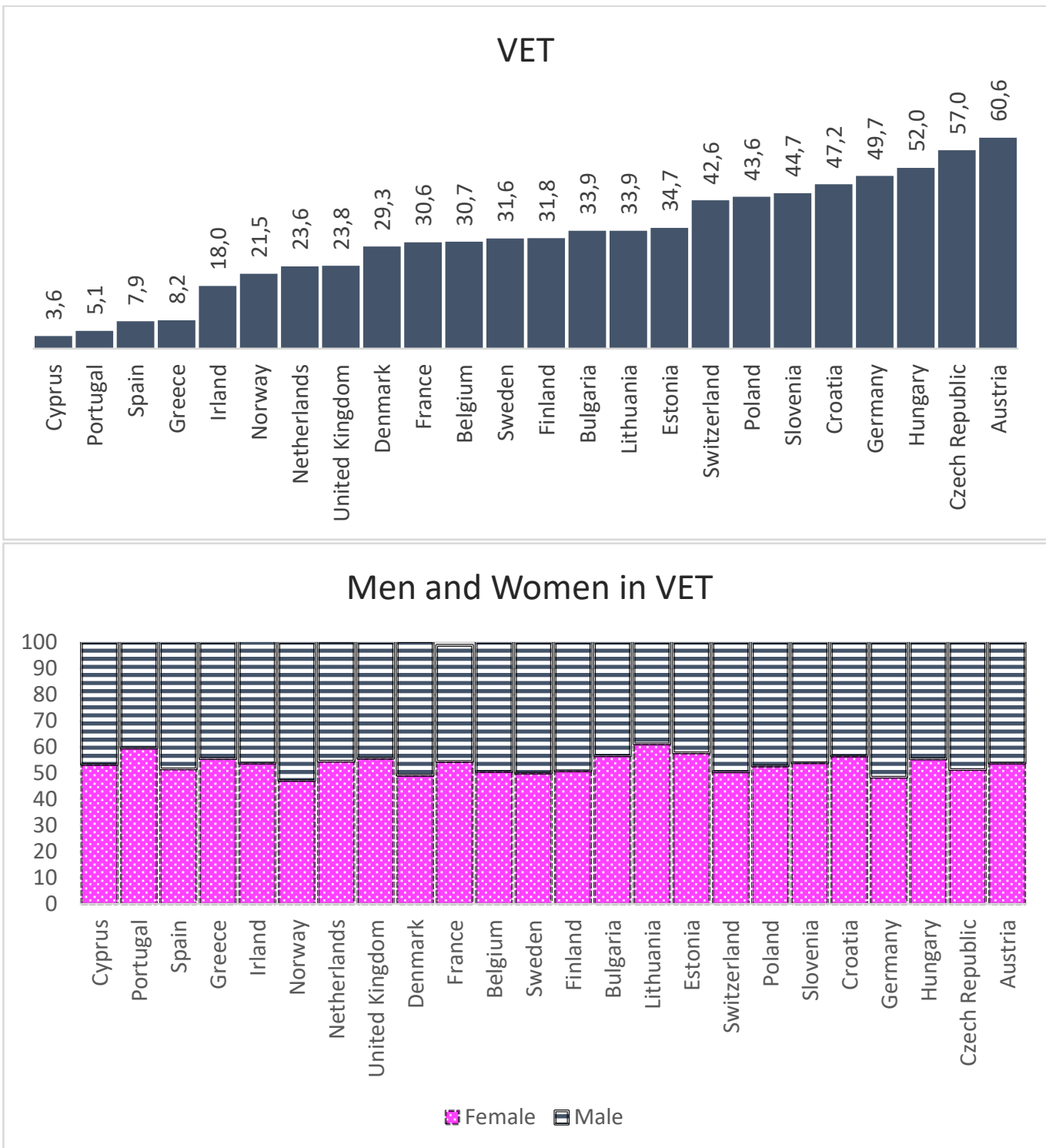


Figure 2. Size of the (male-dominated) blue-collar sector. Average values 2008-2016

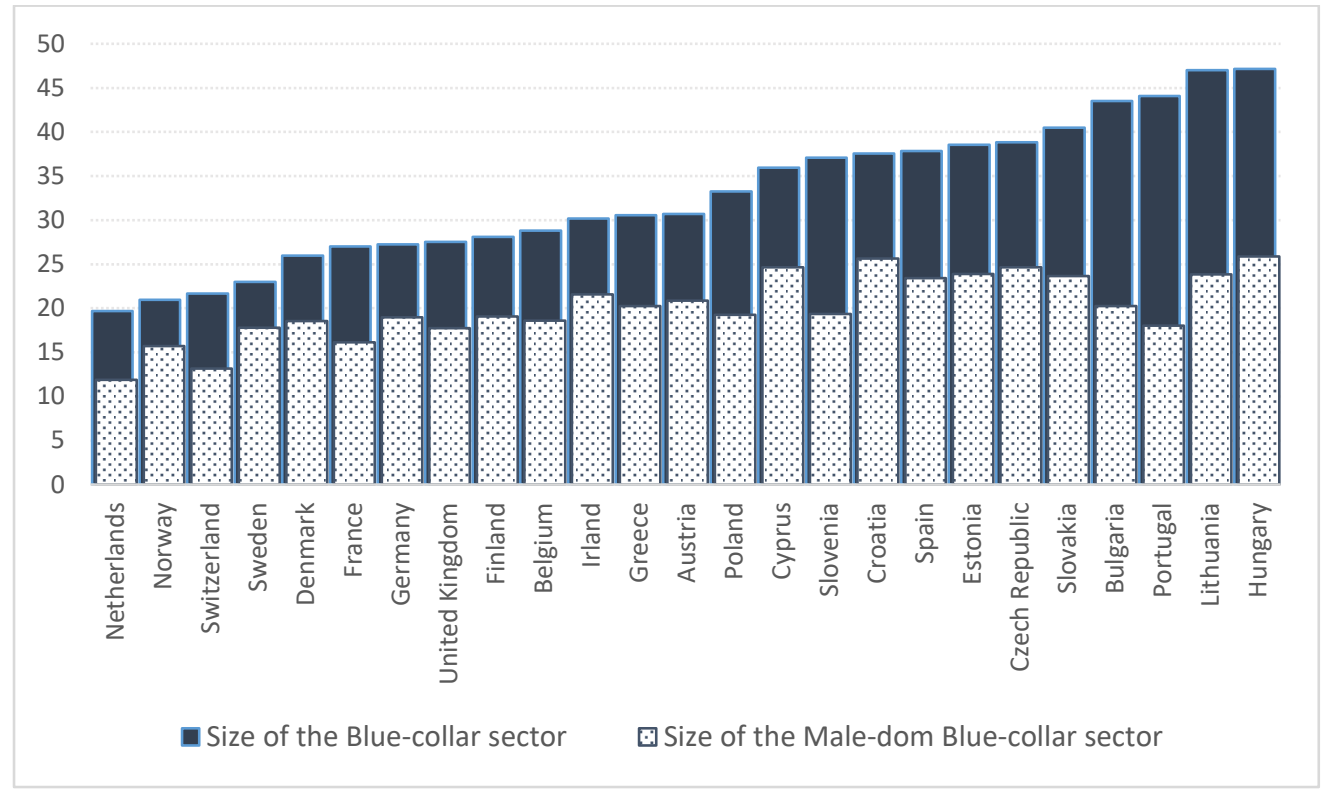


Figure 3. Sex-distribution in blue-collar occupations by country. Average values 2008-2016.

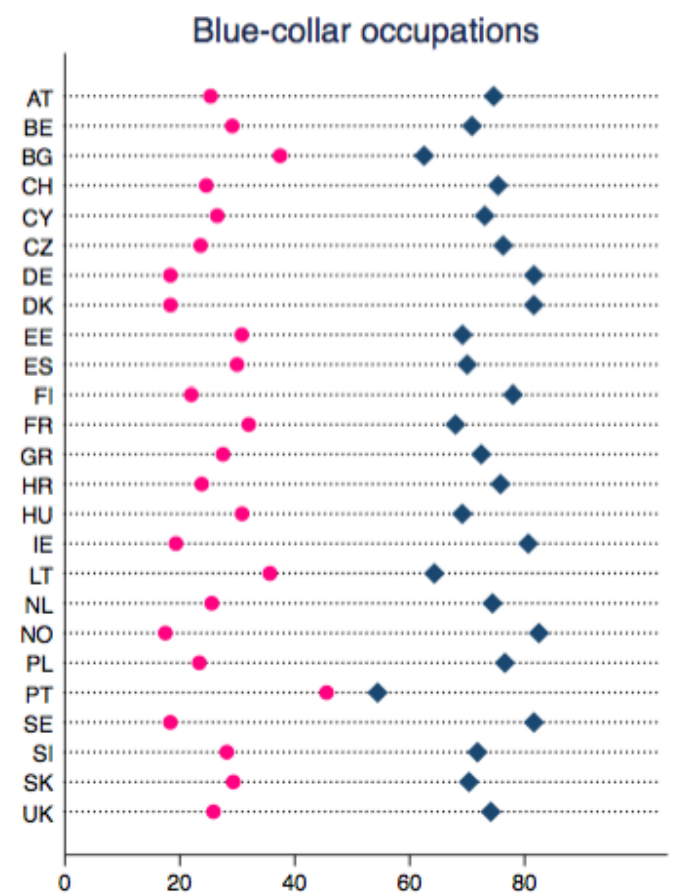

\section{Male-dominated blue-collar occupations}

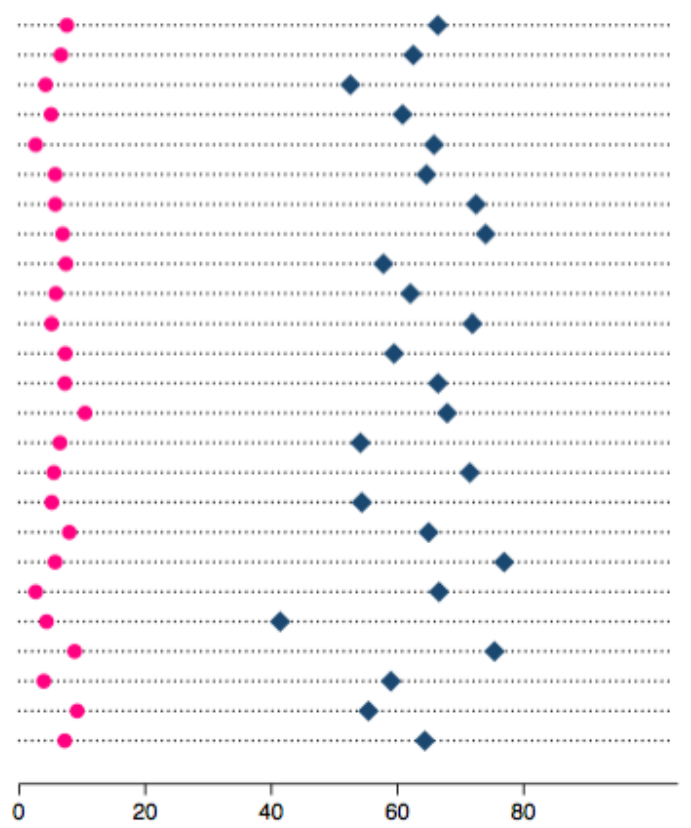

Men Women 
Figure 4. Ratio income decile male-dominated blue-collar jobs and female-dominated blue-collar jobs.

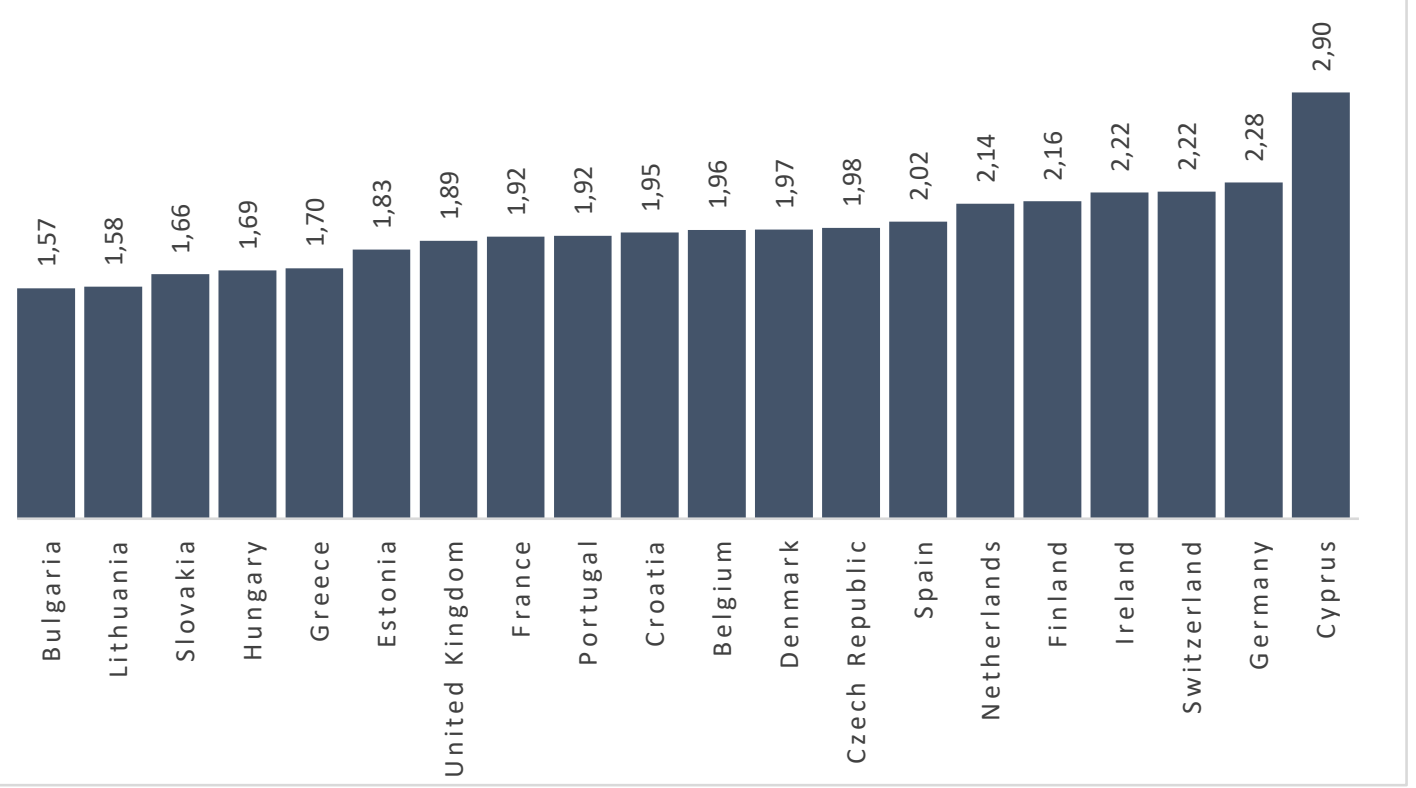

Source: LFS 2015. Only countries where data are available. 
Figure 5. Probability of being employed in the blue-collar sector by level of VET.

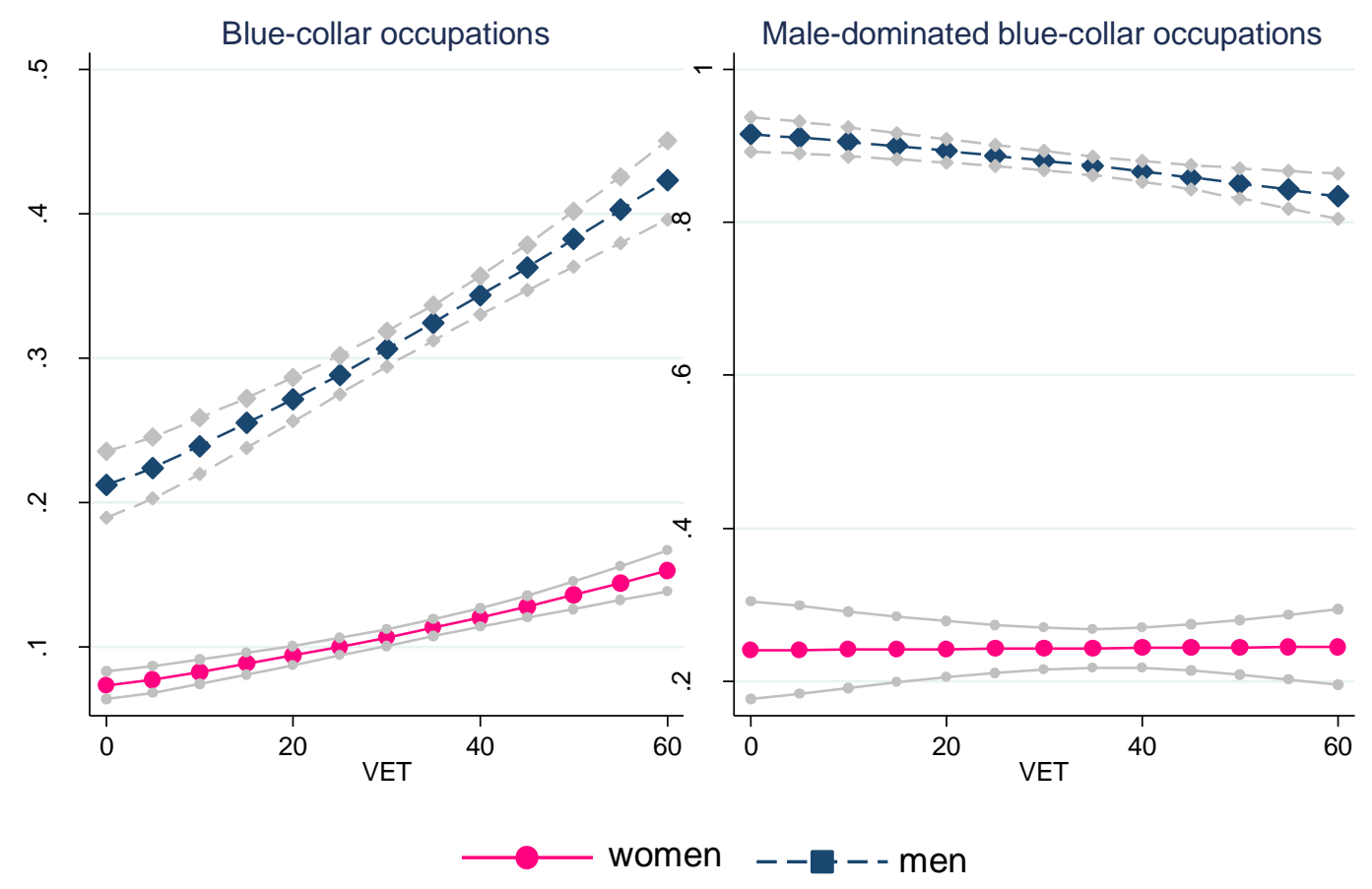


Figure 6. Probability of being employed in the blue-collar sector by parents' education and working characteristics
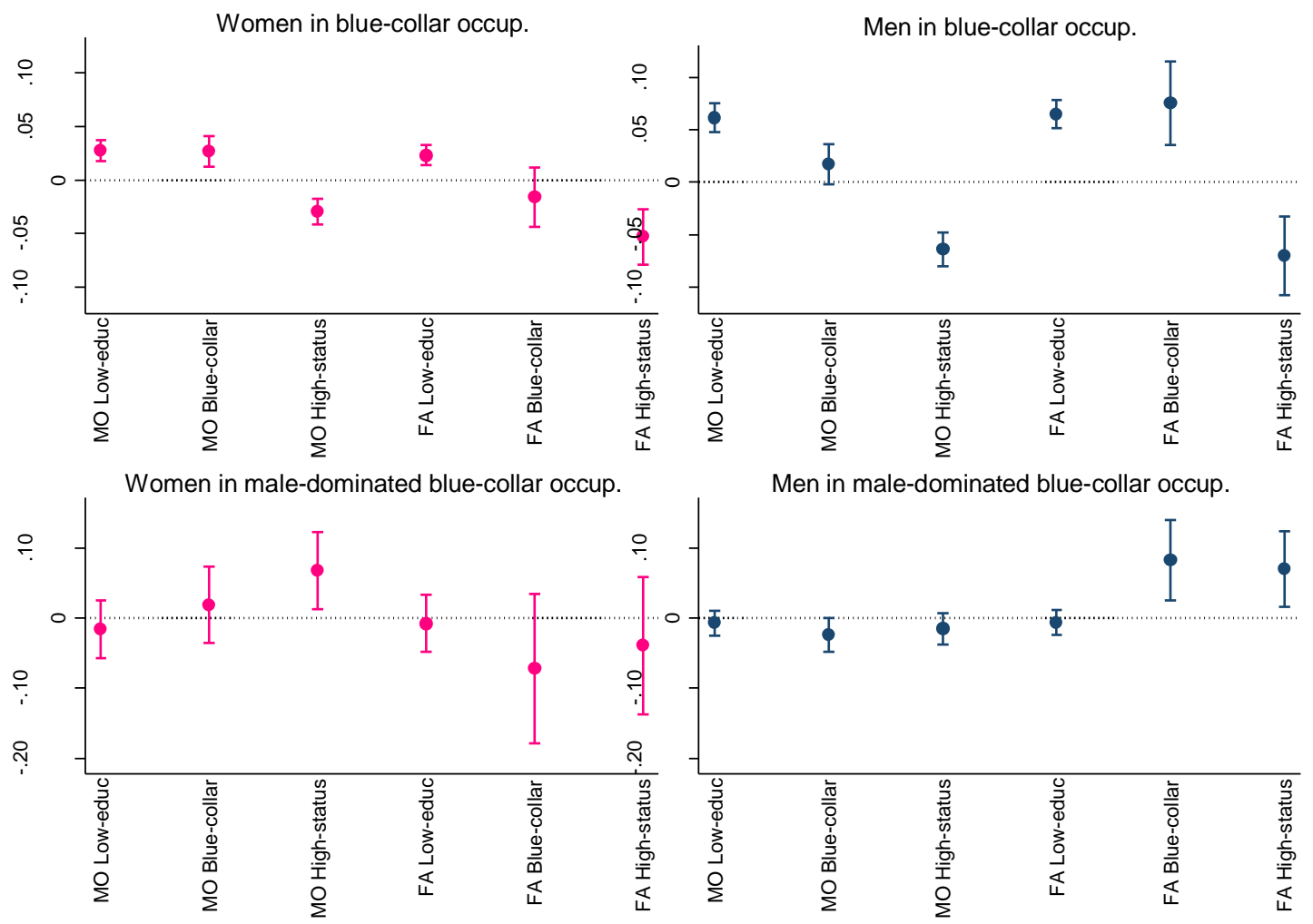

Note: $d y / d x$ for Mother's working status and Father's working status is the discrete change from the base level (unemployed) 
Appendix A. Data availability. Country/year

\begin{tabular}{lccccc}
\hline & $\mathbf{2 0 0 8}$ & $\mathbf{2 0 1 0}$ & $\mathbf{2 0 1 2}$ & $\mathbf{2 0 1 4}$ & $\mathbf{2 0 1 6}$ \\
\hline Austria & & & & 962 & 1119 \\
Belgium & 878 & 827 & 895 & 860 & 839 \\
Bulgaria & 982 & 896 & 923 & & \\
Czech Republic & 988 & 837 & 847 & 853 & 881 \\
Croatia & 428 & 527 & & & \\
Cyprus & 671 & 525 & 526 & & \\
Denmark & 834 & 820 & 825 & 773 & \\
Estonia & 879 & 848 & 1191 & 1104 & 1134 \\
Finland & 1161 & 879 & 107 & 970 & 886 \\
France & 1032 & 858 & 921 & 898 & 908 \\
Germany & 1376 & 1489 & 1421 & 1541 & 1505 \\
Greece & 1165 & 1049 & & & \\
Hungary & 623 & 734 & 869 & 823 & \\
Ireland & 773 & 936 & 1047 & 1021 & 1325 \\
Letonia & & 584 & 1023 & 1109 & \\
Norway & 970 & 916 & 983 & 827 & 873 \\
Poland & 754 & 846 & 903 & 778 & 841 \\
Portugal & 943 & 795 & 829 & 514 & \\
Slovakia & 814 & 803 & 879 & & 606 \\
Slovenia & 535 & 600 & 492 & 471 & 844 \\
Spain & 1327 & 904 & 800 & 869 & \\
Sweden & 1104 & 827 & 996 & 971 & \\
Switzerland & 1087 & 118 & 1031 & 1151 & 1334 \\
The Netherlands & 912 & 917 & 886 & 900 & 797 \\
United Kingdom & 1184 & 1172 & 997 & 1059 & 978 \\
\hline \hline
\end{tabular}


Appendix B. Descriptives of individual-level predictors

\begin{tabular}{|c|c|c|c|c|c|c|c|c|c|c|c|c|}
\hline & 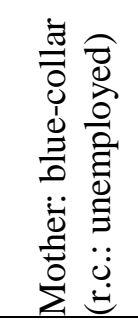 & 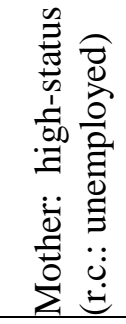 & 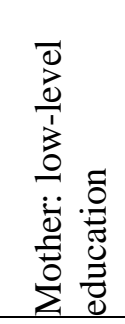 & 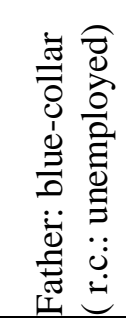 & 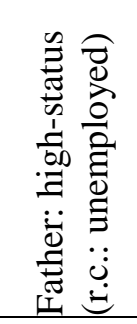 & 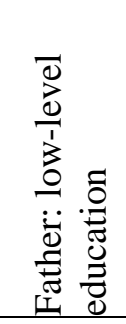 & $\underset{8}{80}$ & $\begin{array}{l}0 \\
0 \\
0 \\
0 \\
0 \\
0 \\
\frac{0}{1} \\
3 \\
0 \\
\end{array}$ & $\begin{array}{l}\frac{0}{000} \\
\stackrel{\Xi}{5}\end{array}$ & 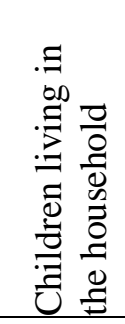 & 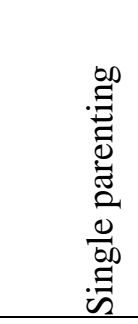 & 咅 \\
\hline \multicolumn{13}{|c|}{ Women } \\
\hline Austria & 0.165 & 0.41 & 0.44 & 0.38 & 0.6 & 0.27 & 41.9 & 0.17 & 0.33 & 0.42 & 0.07 & 0.87 \\
\hline Belgium & 0.13 & 0.36 & 0.52 & 0.26 & 0.69 & 0.46 & 40.4 & 0.23 & 0.29 & 0.48 & 0.07 & 0.85 \\
\hline Bulgaria & 0.4 & 0.45 & 0.51 & 0.58 & 0.4 & 0.48 & 45 & 0.23 & 0.16 & 0.53 & 0.06 & 0.99 \\
\hline Croatia & 0.14 & 0.29 & 0.57 & 0.33 & 0.5 & 0.43 & 40.6 & 0.18 & 0.11 & 0.52 & 0.002 & 0.91 \\
\hline Cyprus & 0.18 & 0.25 & 0.71 & 0.22 & 0.76 & 65 & 40.5 & 0.25 & 0.15 & 0.53 & 0.01 & 0.89 \\
\hline Czech Republic & 0.16 & 0.36 & 0.47 & 0.26 & 0.72 & 0.29 & 41.1 & 0.22 & 0.25 & 0.43 & 0.02 & 0.73 \\
\hline Denmark & 0.26 & 0.47 & 0.47 & 0.36 & 0.63 & 0.42 & 42.1 & 0.21 & 0.26 & 0.45 & 0.06 & 0.9 \\
\hline Estonia & 0.38 & 0.52 & 0.3 & 0.67 & 0.31 & 0.35 & 41.9 & 0.14 & 0.3 & 0.5 & 0.13 & 0.85 \\
\hline Finland & 0.3 & 0.49 & 0.44 & 0.42 & 0.55 & 0.46 & 41.8 & 0.15 & 0.21 & 0.4 & 0.05 & 0.94 \\
\hline France & 0.14 & 0.4 & 0.62 & 0.36 & 0.61 & 0.54 & 42.5 & 0.19 & 0.28 & 0.47 & 0.10 & 0.89 \\
\hline Germany & 0.2 & 0.45 & 0.28 & 0.44 & 0.54 & 0.12 & 42 & 0.14 & 0.27 & 0.42 & 0.05 & 0.89 \\
\hline Greece & 0.11 & 0.18 & 0.75 & 0.12 & 0.87 & 0.69 & 40.4 & 0.26 & 0.15 & 0.50 & 0.00 & 0.9 \\
\hline Hungary & 0.43 & 0.27 & 0.49 & 0.69 & 0.27 & 0.36 & 41.3 & 0.19 & 0.23 & 0.47 & 0.04 & 0.97 \\
\hline Ireland & 0.12 & 0.21 & 0.62 & 0.22 & 0.68 & 0.66 & 41.4 & 0.25 & 0.31 & 0.54 & 0.10 & 0.82 \\
\hline Letonia & 0.34 & 0.44 & 0.41 & 0.68 & 0.28 & 0.49 & 41.9 & 0.15 & 0.25 & 0.45 & 0.04 & 0.96 \\
\hline Norway & 0.16 & 0.56 & 0.41 & 0.3 & 0.67 & 0.34 & 40.21 & 0.14 & 0.32 & 0.46 & 0.10 & 0.87 \\
\hline Poland & 0.28 & 0.38 & 0.6 & 346 & 0.5 & 0.64 & 40.4 & 0.29 & 0.22 & 0.54 & 0.03 & 0.99 \\
\hline Portugal & 0.24 & 0.21 & 0.9 & 0.36 & 0.61 & 0.89 & 43.2 & 0.62 & 0.21 & 0.48 & 0.05 & 0.91 \\
\hline Slovakia & 0.33 & 0.4 & 0.44 & 0.6 & 0.36 & 0.35 & 44.1 & 0.12 & 0.13 & 0.49 & 0.03 & 0.97 \\
\hline Slovenia & 0.25 & 0.35 & 0.5 & 0.47 & 0.41 & 0.36 & 41.7 & 0.2 & 0.31 & 0.54 & 0.09 & 0.91 \\
\hline
\end{tabular}




\begin{tabular}{|c|c|c|c|c|c|c|c|c|c|c|c|c|}
\hline Spain & 0.16 & 0.19 & 0.85 & 0.25 & 0.71 & 0.79 & 40.2 & 0.48 & 0.24 & 0.51 & 0.03 & 0.88 \\
\hline Sweden & 0.19 & 0.57 & 0.41 & 0.36 & 0.62 & 0.45 & 41.1 & 0.12 & 0.34 & 0.44 & 0.1 & 0.86 \\
\hline Switzerland & 0.37 & 0.5 & 0.19 & 0.63 & 0.36 & 0.11 & 41.7 & 0.13 & 0.22 & 0.44 & 0.03 & 0.98 \\
\hline The Netherlands & 0.09 & 0.32 & 0.73 & 0.21 & 0.74 & 0.62 & 42.6 & 0.33 & 0.26 & 0.47 & 0.06 & 0.89 \\
\hline United Kingdom & 0.25 & 0.38 & 0.64 & 0.39 & 0.55 & 0.57 & 41.9 & 0.3 & 0.36 & 0.47 & 0.1 & 0.86 \\
\hline & \multicolumn{12}{|c|}{ Men } \\
\hline Austria & 0.16 & 0.38 & 0.48 & 0.4 & 0.57 & 0.26 & 42.7 & 0.12 & 0.38 & 0.33 & 0.04 & 0.89 \\
\hline Belgium & 0.14 & 0.34 & 0.53 & 0.27 & 0.68 & 0.47 & 40.3 & 0.26 & 0.33 & 0.43 & 0.06 & 0.86 \\
\hline Bulgaria & 0.39 & 0.46 & 0.52 & 0.57 & 0.41 & 0.49 & 44.2 & 0.21 & 0.25 & 0.41 & 0.04 & 0.99 \\
\hline Croatia & 0.13 & 27 & 0.59 & 0.34 & 0.5 & 0.45 & 42.1 & 0.12 & 0.15 & 0.46 & 0.00 & 0.9 \\
\hline Cyprus & 0.15 & 0.23 & 0.65 & 0.18 & 0.81 & 0.61 & 0.4 & 0.19 & 0.21 & 0.42 & 0.01 & 0.89 \\
\hline Czech Republic & 0.13 & 0.34 & 0.45 & 0.23 & 0.75 & 0.3 & 40.4 & 0.17 & 0.31 & 0.37 & 0.02 & 0.74 \\
\hline Denmark & 0.25 & 0.48 & 0.48 & 0.34 & 0.64 & 0.41 & 41.3 & 0.22 & 0.30 & 0.39 & 0.3 & 0.93 \\
\hline Estonia & 0.35 & 0.54 & 0.28 & 0.65 & 0.34 & 0.32 & 39.9 & 0.19 & 0.39 & 0.37 & 0.08 & 0.88 \\
\hline Finland & 0.3 & 0.49 & 0.46 & 0.41 & 0.57 & 0.46 & 42.2 & 0.18 & 0.25 & 0.34 & 0.03 & 0.95 \\
\hline France & 0.12 & 0.4 & 0.59 & 0.35 & 0.61 & 0.5 & 42.7 & 0.18 & 0.32 & 0.38 & 0.06 & 0.9 \\
\hline Germany & 0.21 & 0.43 & 0.28 & 0.44 & 0.54 & 0.11 & 41.9 & 0.12 & 0.32 & 0.35 & 0.03 & 0.89 \\
\hline Greece & 0.11 & 0.18 & 0.73 & 0.13 & 0.85 & 0.7 & 39.4 & 0.26 & 0.24 & 0.37 & 0.00 & 0.91 \\
\hline Hungary & 0.43 & 0.27 & 0.49 & 0.69 & 0.27 & 0.34 & 40.6 & 0.16 & 0.28 & 0.38 & 0.03 & 0.98 \\
\hline Ireland & 0.11 & 0.2 & 0.6 & 0.21 & 0.69 & 0.64 & 40.6 & 0.31 & 0.4 & 0.35 & 0.03 & 0.8 \\
\hline Letonia & 0.34 & 0.45 & 0.36 & 0.65 & 0.31 & 0.45 & 40.9 & 0.21 & 0.31 & 0.36 & 0.02 & 0.96 \\
\hline Norway & 0.15 & 0.52 & 0.42 & 0.3 & 0.67 & 0.35 & 40.8 & 0.13 & 0.35 & 0.42 & 0.08 & 0.88 \\
\hline Poland & 0.28 & 0.4 & 0.58 & 0.44 & 0.53 & 0.63 & 39.5 & 0.4 & 0.29 & 0.46 & 0.01 & 0.99 \\
\hline Portugal & 0.21 & 0.23 & 0.87 & 0.35 & 0.63 & 0.87 & 41.2 & 0.59 & 0.26 & 0.36 & 0.03 & 0.91 \\
\hline Slovakia & 0.34 & 0.41 & 0.38 & 0.63 & 0.34 & 0.28 & 42.8 & 0.08 & 0.20 & 0.50 & 0.02 & 0.97 \\
\hline Slovenia & 0.25 & 0.37 & 0.48 & 0.45 & 0.42 & 0.33 & 40.9 & 0.17 & 0.37 & 0.47 & 0.08 & 0.91 \\
\hline Spain & 0.13 & 0.19 & 0.84 & 0.21 & 0.76 & 0.79 & 40.1 & 0.52 & 0.29 & 0.43 & 0.03 & 0.88 \\
\hline Sweden & 0.19 & 0.55 & 0.42 & 0.35 & 0.63 & 0.44 & 40.4 & 0.16 & 0.39 & 0.41 & 0.09 & 0.87 \\
\hline Switzerland & 0.38 & 0.49 & 0.18 & 0.62 & 0.37 & 0.11 & .41 .3 & 0.13 & 0.28 & 0.33 & 0.01 & .98 \\
\hline The Netherlands & 0.08 & 0.28 & 0.73 & 0.18 & 0.77 & 0.63 & 43.5 & 0.31 & 0.29 & 0.37 & 0.28 & 0.89 \\
\hline United Kingdom & 0.24 & 0.37 & 0.65 & 0.38 & 0.57 & 0.58 & .42 .6 & 0.28 & 0.3 & 0.35 & 0.04 & 0.85 \\
\hline
\end{tabular}


Appendix C. Multilevel Logistic Regression of employment in the blue-collar fields. Women and men less than 35 years old.

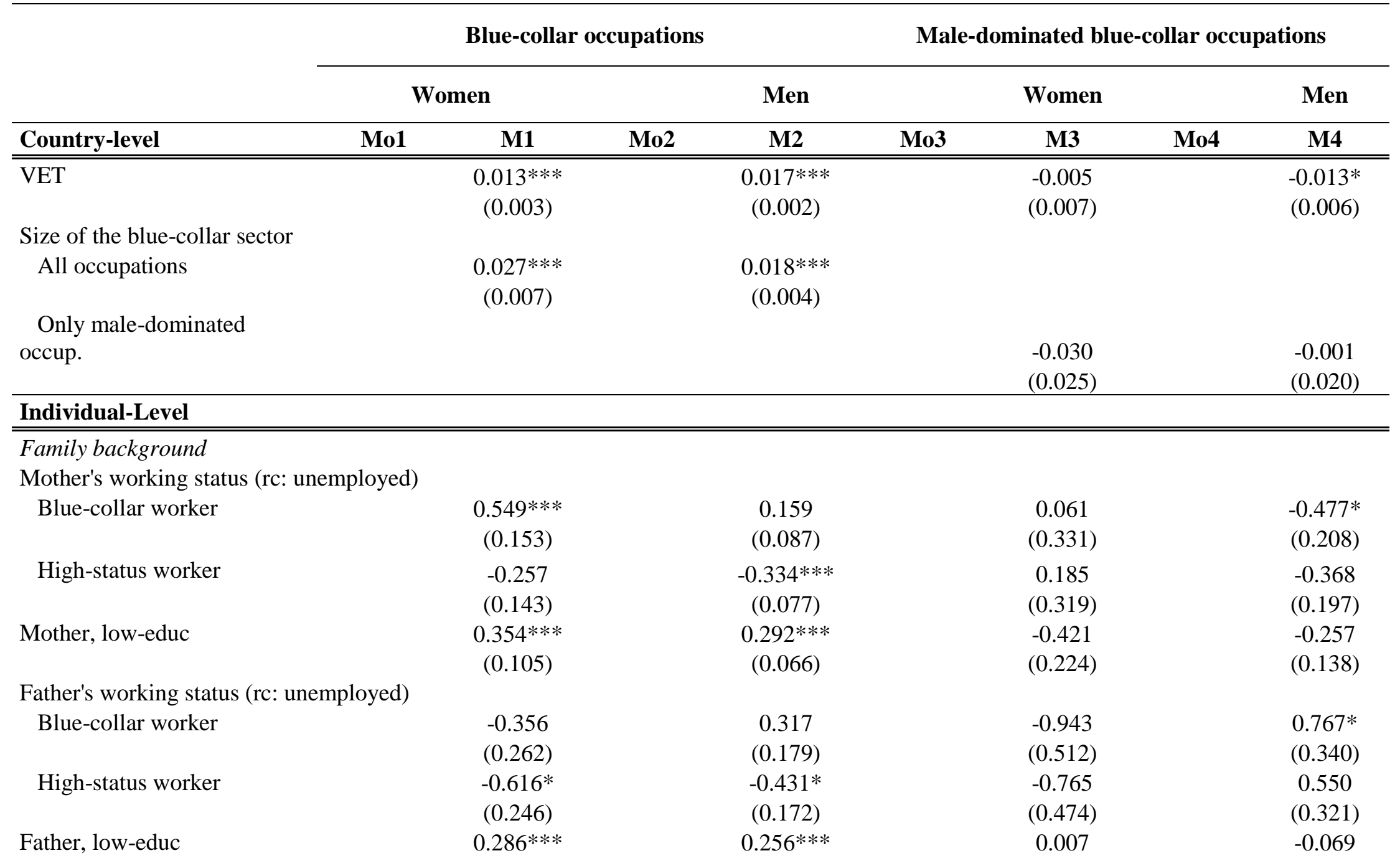




\begin{tabular}{|c|c|c|c|c|c|c|c|c|}
\hline \multirow{2}{*}{\multicolumn{9}{|c|}{ Control variables }} \\
\hline & & & & & & & & \\
\hline \multirow[t]{2}{*}{ Age } & & $-0.047 * * *$ & & $-0.081 * * *$ & & $0.063^{*}$ & & 0.003 \\
\hline & & $(0.010)$ & & $(0.006)$ & & $(0.020)$ & & $(0.012)$ \\
\hline \multirow[t]{2}{*}{ Low-edu } & & $1.509 * * *$ & & $1.079 * * *$ & & -0.216 & & $-0.385^{* *}$ \\
\hline & & $(0.110)$ & & $(0.079)$ & & $(0.216)$ & & $(0.134)$ \\
\hline \multirow[t]{2}{*}{ Single } & & 0.050 & & -0.033 & & -0.265 & & -0.276 \\
\hline & & $(0.121)$ & & $(0.069)$ & & $(0.249)$ & & $(0.157)$ \\
\hline \multirow[t]{2}{*}{ Children in the household } & & $0.441 * * *$ & & $0.242 * *$ & & $-0.954 * * *$ & & -0.002 \\
\hline & & $(0.122)$ & & $(0.075)$ & & $(0.256)$ & & $(0.170)$ \\
\hline \multirow[t]{2}{*}{ Single parenting } & & 0.132 & & $0.395 * * *$ & & $0.715^{*}$ & & 0.478 \\
\hline & & $(0.175)$ & & $(0.116)$ & & $(0.357)$ & & $(0.260)$ \\
\hline Native-born & & $\begin{array}{c}-1.026 * * * \\
(0.113)\end{array}$ & & $\begin{array}{l}-0.157 \\
(0.084)\end{array}$ & & $\begin{array}{c}0.680^{* *} \\
(0.246)\end{array}$ & & $\begin{array}{c}0.576 * * * \\
(0.169)\end{array}$ \\
\hline Intercept & $\begin{array}{c}-1.999 * * * * \\
(0.051) \\
\end{array}$ & $\begin{array}{c}-1.554 * * * \\
(0.435) \\
\end{array}$ & $\begin{array}{c}-0.443 * * * \\
(0.034) \\
\end{array}$ & $\begin{array}{l}0.569^{*} \\
(0.285) \\
\end{array}$ & $\begin{array}{c}-1.073 * * * \\
(0.079) \\
\end{array}$ & $\begin{array}{c}-1.081 * * \\
(0.089) \\
\end{array}$ & $\begin{array}{c}1.842^{* * * *} \\
(0.065) \\
\end{array}$ & $\begin{array}{c}2.052 * * * \\
(0.612) \\
\end{array}$ \\
\hline \multicolumn{9}{|l|}{ Random Effects } \\
\hline sd (Intercept) & $\begin{array}{c}0.453 * * * \\
(0.040)\end{array}$ & $\begin{array}{c}0.315^{* * *} \\
(0.058)\end{array}$ & $\begin{array}{c}0.314 * * * \\
-0.0287\end{array}$ & $\begin{array}{c}0.248 * * * \\
(0.035)\end{array}$ & $\begin{array}{c}0.617 * * * \\
(0.077)\end{array}$ & $\begin{array}{c}0.532 * * * \\
(0.103)\end{array}$ & $\begin{array}{c}0.554 * * * \\
(0.056) \\
\end{array}$ & $\begin{array}{c}0.568 * * * \\
(0.079) \\
\end{array}$ \\
\hline
\end{tabular}

